\title{
HVORFOR VI ELSKER ROLAND BARTHES
}

\author{
ANMELDELSE AF \\ Carsten Meiner (red.): Roland Barthes. En antologi, København, 2007 (Museum Tuscu- \\ lanums Forlag)
}

Roland Barthes er vel en af de mest benyttede teoretikere i de kunst- og kulturvidenskabelige universitetsfags kompendier de seneste 30-40 år og er da også i stort omfang oversat til dansk (begyndende med Litteraturens nulpunkt, der udkom på dansk i 1968, 15 år efter den franske original), men han har i Danmark primært været én, hvis elegante tekster man benytter til at analysere noget andet med, og i mindre grad en teoretiker, hvis tænkning er blevet gjort til selve genstanden for analysen. Dette rådes der bod på med den fremragende og yderst informative Roland Barthes. En antologi, redigeret af Carsten Meiner, der også tidligere glimrende har oversat Barthes' Forfatterens død og andre essays (2004).

Noget af det, der kendetegner Roland Barthes, er hans bevægelighed og, som Meiners forord gør opmærksom på, hans konstante udvikling, der går gennem eksistentialisme, ideologikritik, semiologi, strukturalisme, psykoanalyse og poststrukturalisme, men med en række genkommende tematiske og begrebslige tværgående konstanter: "Utopien, institutionen, forfatteren, tegnet, skriften, begæret, romanen, teatret, æstetikken og fotoet." (18). Det er disse "konstanter”, der behandles af en række både yngre og mere etablerede danske, og en enkelt norsk, litteraturhistorikere og æstetikteoretikere i Roland Barthes. En antologi.

Således analyserer Nikolaj Lübecker utopien som kategori i Barthes' forfatterskab, fra Litteraturens nulpunkt til de sidste års forelæsninger om "det neutrale”. John Thobo-Carlsen giver med afsæt i Barthes' egen udtalelse fra 1975: "I skæringspunktet for hele værket, måske Teatret," en omfattende redegørelse for Barthes' interesse for teatraliteten som det, der binder hans værk sammen og er med til at give det konsistens. Jørn Boisen behandler og diskuterer Barthes’ strukturalistiske læsning af Jean Racine, den store franske klassicistiske digter, og den hermed forbundne problematisering af hidtidig akademisk praksis, fx opfattelsen af forfatteren som værkets entydige oprindelse, samt den litteraturvidenskabelige polemik, som fulgte, og dette nye videnskabelige paradigmes konsekvenser for humaniora.

Anders Toftgaard beskriver Barthes' semiologiske eller semiotiske praksis og 
redegør for hans hele tiden bevægelige tegnteori, der, som Toftgaard argumenterer, aldrig stivner og bliver til det af strukturalismen ønskede videnskabelige system. Barthes måtte derfor også ved tiltrædelsen af professoratet i litterær semiologi ved Collège de France i 1977 erkende, at hans produktion bestod af essays, "denne tvetydige genre, hvor skriften rivaliserer med analysen”. Peter Borum udvikler i sit tætvævede bidrag en tekstnydelsens etik hos Barthes, hvor der er tale om en libidinalt investeret, seksuel omgang med teksten. Teksten frembringes af en skrift, som bærer dens værdi, og som identificeres med en drift, der ikke er forbeholdt det menneskelige, men er fælles med verden; en singulær skrift, som udgrænser det ideologiske.

Julio Jensen behandler forfatterproblemet og Barthes' selvbiografi fra 1975, Roland Barthes par Roland Barthes (Afmig selv), i lyset af den berømte/berygtede tekst om "Forfatterens død" fra 1968 (ret beset blev teksten allerede publiceret i 1967 i en relativt overset amerikansk oversættelse i Aspen Magazine 5-6), idet han sympatisk argumenterer for, at der bag selvbiografien befinder sig en subjektivitet i form af en selvbevidst forfatter, som negerer Subjektet med stort S ved at lade en af tekst og drifter født anti-subjektivitet komme til syne - man kunne her få associationer til den beskrivelse, Wolfgang Iser i begyndelsen af 70'erne gav af den beckettske subjektivitet som "selvophævelsen af dens egne manifestationer". Frederik Tygstrup analyserer Barthes' teoretiseringer over romanen, idet han forstår den sene Barthes' romanfascination som et ønske om at opfinde en ny, personlig måde at skrive på, som bryder med det akademiske, videnskabelige metasprog. På den baggrund viser Tygstrup overbevisende, hvordan Barthes' tre sidste bøger - selvbiografien, Karlighedens forrykte tale og Det lyse kammer - trækker på romanprojektet og på forskellig vis peger frem mod denne nye skrivemåde, der som en tredje form, den nye "roman", muliggør et møde mellem "fragmentet som sandhedschiffer" og "det imaginære billede af selvet”.

Arnfinn Bø-Rygg afdækker æstetikken i Barthes’ forfatterskab, en æstetik, der ifølge Barthes' eget udsagn skal ledes bort fra "dens regressive, idealistiske grundlag” og tilnærmes kroppen og afdriften. Bø-Rygg bemærker, at Barthes foregriber æstetikkens udvikling de seneste årtier, hvor den netop ikke blot drejer sig om kunst og det skønne, men om sansemæssig erfaring, og viser, hvordan den sene Barthes i sin omgang med musik og maleri, især Schumann og Twombly, etablerer en æstetisk diskurs "der kroppsfornemmelsene får komme til uttrykk, som en form for erkjennelse. Det dreier seg om å protokollere presis og individuell erfaring i hvert enkelt tilfelle" (det er især denne sans for det singulære, der på tværs af antologien opskattes og fremhæves). Det er ligeledes derfor, Bø-Rygg opholder sig ved Barthes’ idiosynkrasier - hans lister over, hvad han elsker og ikke elsker, i Afmig selv-som en æstetisk forholden sig til verden, og som en udpegning af et associationsrum, der ligger under subjektiviteten og udgør dens bestanddele, og som tilkendegiver "det individuelle, det udelelige, det ikke-identiske”. Bø-Rygg lader Barthes selv forklare idiosynkrasiens vigtige æstetikvidenskabelige indsigt: "jeg elsker/elsker ikke: det har ingen betydning for noen; det har tilsyneladende ingen mening. Og dog betyder alt 
dette: min krop er ikke den samme som din." Endelig giver Peter Larsen en redegørelse for Barthes' mange tekster om fotografiet, der både rummer analyser af konkrete fotografier og refleksioner over fotografiets ontologiske status, og hvordan Barthes også her på én gang holder fast ved de samme temaer og problematikker og udvikler sin måde at tale, og dermed tænke, om disse på, for mere fænomenologisk i sin sidste bog, Det lyse kammer, at lade det individuelle punctum, et fotografis betydning for netop mig, få plads og krydse den kulturelle, kollektive betydning, som det videnskabelige studium er en afkodning af.

Bidragene belyser dermed en vifte af de vigtigste temaer og problematikker i Barthes' omfattende forfatterskab og er generelt velskrevne, substantielle og yderst veldokumenterede - skribenterne kan deres Barthes! Samtlige bidrag vidner om et indgående kendskab til Barthes' produktion og til dennes kontekst, hvilket også afspejles i de - for den interesserede læser, der ønsker at forske videre i de behandlede emner og tematikker, særdeles nyttige - mange litteraturhenvisninger og slutnoter (Anders Toftgaard tager prisen med ikke færre end 117 noter). Særligt træder Borums, Tygstrups og Bø-Ryggs artikler frem, idet de ud over loyalt at redegøre for Barthes' teorier samtidigt elegant bearbejder disse og afdækker, i det mindste for denne anmelder, upåagtede sammenhænge og konsekvenser.

Antologien, der ligeledes er forsynet med en gennemgang af Barthes' liv og produktion samt en udførlig bibliografi, er overordentlig vellykket som introduktion til Barthes' forfatterskab - det kan ganske enkelt vanskeligt gøres bedre - og den efterlader ingen tvivl om hans vigtighed og fortsatte relevans i en lang række henseender. Man kommer dog ikke, hvilket der heller ikke lægges skjul på hos forfatterne, uden om en vis tidsbundethed i flere af Barthes' teoretiske pointer - dette er på én gang deres styrke og svaghed. Som den amerikanske filosof Larry Shiner, der opholdt sig i Paris i sidste halvdel af 60'erne og blandt andet overværede nogle af Barthes' forelæsninger, på et tidspunkt sagde til mig: 'tidligere elskede jeg at læse Barthes'. Det gjorde han egentlig stadig, men "without the faith". Og det er ofte sådan, vi læser Barthes i dag: Vi beundrer ham for hans formidlingsevne, hans retoriske begavelse og hans glæde ved teksten, men vi har iblandt svært ved helt at tro på og tilslutte os indholdet i det, han skriver, f.eks. vedrørende "Forfatterens død" (skønt denne lige som flere andre tekster naturligvis skal ses som et manifest eller et partsindlæg $\mathrm{i}$ en debat, hvor tankens tydeliggørelse indimellem må overskygge dens nuancering). I en tid, hvor forskning promiskuøst kopuleres med faktura, er disse elskelige dyder imidlertid mere kærkomne end nogensinde, og Roland Barthes. En antologi tydeliggør uden ukritisk akklamation, hvorfor - med en omskrivning af Barthes' anmeldelse af lingvisten Émile Benveniste - det er sådan, at vi læser andre kunst- og kulturteoretikere, men elsker Roland Barthes!

Jacob Lund er adjunkt ved Institut for Æstetiske Fag, Aarhus Universitet 